\title{
LEGAL REFORM DALAM PENJATUHAN SANKSI TERHADAP ANAK PELAKU KEJAHATAN
}

\author{
Ni Nyoman Juwita Arsawati(1); AAA.Ngr.Tini Rusmini Gorda(2) \\ admisi@pasca-undiknas.ac.id ${ }^{(1)}$,admisi@pasca-undiknas.ac.id ${ }^{(2)}$ \\ Undiknas University, Denpasar, Bali
}

\begin{abstract}
The child needs to be protected both physically and spiritually, especially when the child is a criminal. Children to be accountable for their actions, not separated from the imposition of criminal punishment of imprisonment. The imposition of imprisonment on children is irrelevant compared to the crime rate, and it seems that imprisonment does not deter the perpetrator. It can be attributed to a child's crime similar to that of an adult whether in quantity or quality. This situation certainly raises issues both philosophically, juridically and sociologically. It is deemed necessary to reform the criminal law in the face of children as perpetrators of crime, deprivation of liberty by placing children in prison, unable to provide protection from the deprivation of the rights of children as opposed to the values of Pancasila as stipulated in the second precept " humanitarian "so it is necessary to replace it with alternative criminal (alternative sanction) one of them in the form of criminal supervision as regulated in Article 71 of Law No.11 Year 2012 About Child Criminal Justice System. Characteristics of the imposition of criminal surveillance of the child, perpetrators are still given the opportunity to improve themselves, and supervision is made in accordance with the personal needs of children who promote human coaching, by upholding the dignity of children based on the principle of "humanity". This is certainly in accordance with the idea or ideals of law and the reality of society that is upholding a democratic, social and humane life, which became the basic color of Indonesian law based on Pancasila.

Keywords :Llegal reform, children of perpetrators of crime, imposition of sanctions
\end{abstract}

\section{ABSTRAK}

Anak perlu mendapatkan perlindungan secara jasmani maupun rohani, khususnya pada saat anak sebagai pelaku kejahatan. Anak untuk mempertanggungjawabkan perbuatannya, tidak lepas dari penjatuhan pidana berupa pidana penjara. Penjatuhan pidana penjara pada anak sudah tidak relevan dibandingkan dengan tingkat kejahatan yang terjadi, dan nampaknya pidana penjara justru tidak membuat jera bagi pelaku. Hal tersebut dapat dikaitkan dengan kejahatan yang dilakukan anak hampir sama dengan yang dilakukan orang dewasa baik secara kuantitas maupun kualitas. Keadaan tersebut tentunya menimbulkan persoalan baik secara filosofis, yuridis maupun sosiologis. Dipandang perlu untuk melakukan pembaruan hukum pidana di dalam menghadapi anak sebagai pelaku kejahatan, perampasan kemerdekaan dengan menempatkan anak di dalam penjara, tidak dapat memberikan perlindungan dari perampasan hak-hak anak karena bertentangan dengan nilai-nilai Pancasila yang tertuang di dalam sila ke-2 "kemanusiaan" sehingga perlu untuk menggantikannya dengan pidana alternatif (alternative sanction) salah satunya berupa pidana pengawasan yang diatur dalam Pasal 71 UndangUndang No.11 Tahun 2012 Tentang Sistem Peradilan Pidana Anak. 
Karakteristik penjatuhan pidana pengawasan terhadap anak, pelaku masih diberikan kesempatan untuk memperbaiki diri, dan pengawasan dilakukan disesuaikan dengan kebutuhan pribadi anak yang mengedepankan pembinaan secara manusiawi, dengan menjunjung tinggi harkat dan martabat anak yang berdasarkan pada asas "kemanusiaan". Hal tersebut tentunya sesuai dengan ide atau cita hukum dan realitas masyarakat yaitu menegakkan kehidupan yang demokratis, berkeadilan sosial dan berperikemanusiaan, yang menjadi warna dasar hukum Indonesia yang berdasarkan pada Pancasila.

Kata kunci: legal reform, anak pelaku kejahatan, penjatuhan sanksi

\section{A. PENDAHULUAN}

Realitas keadaan anak di muka bumi ini masih belum menggembirakan, nasib anak belum seindah dari ungkapan yang kerapkali memposisikan anak "sangat bernilai", begitu juga anak sebagai "generasi muda penerus masa depan bangsa". Sesungguhnya secara yuridis untuk mewujudkan sumber daya manusia Indonesia yang berkualitas, diperlukan pembinaan secara terus menerus terhadap anak dengan tanpa mengabaikan pertumbuhan dan perkembangan fisik mental anak demi kelangsungan hidup anak di masa mendatang. Begitu pula secara teoritis dalam memberikan perlindungan terhadap anak harus diberikan prioritas yang terbaik. Keadaan tersebut teraspirasi dari nilai-nilai Pancasila yaitu Ketuhanan Yang Maha Esa dan kemanusiaan yang adil dan beradab, atas dasar itu, Indonesia sebagai bangsa yang bermartabat dan menjunjung tinggi nilai-nilai religius, diharapkan para penegak hukum yang menangani masalah anak harus mampu mengaspirasi nilai-nilai Pancasila.

Usulan DPR dalam risalah pembentukan Undang-Undang No. 11 Tahun 2012 Tentang Sistem Peradilan Pidana Anak, mengusulkan agar dalam proses peradilan pidana anak menjauhkan "pembalasan", dan sebaliknya memberikan perlindungan terhadap anak terkait pada hak asasi anak untukdapat tumbuh dan berkembang sesuai dengan harkat dan martabat.

Masyarakat Internasional melalui Konvensi Hak-Hak Anak (Convention on The Rights of The Child) menaruh perhatian yang begitu besar dalam memberikan perlindungan terhadap hak-hak anak melalui sidang Majelis Umum Perserikatan Bangsa-Bangsa pada tanggal 20 November 1989, dan menjadi instrumen Internasional, yang mengikat secara hukum bagi negara-negara yang meratifikasi. Indonesia salah 
satunya meratifikasi konvensi tersebut melalui Keputusan Presiden No.36 Tahun 1990 tentang Pengesahan Konvensi Hak-Hak Anak pada tanggal 25 Agustus 1990 (Lembaran Negara Republik Indonesia Tahun 1990 Nomor 57). Sebagai dampak dari ratifikasi tersebut bagi Indonesia yaitu, setiap produk hukum yang terkait pada anak, wajib untuk berpedoman pada Konvensi Hak-Hak Anak tersebut.

Konvensi Internasional lainnya yang dianggap penting juga dalam memberikan perlindungan terhadap hak-hak anak bilamana anak berkonflik dengan hukum (Children in Conflict with the Law) yaitu The United Nations Standard Minimum Rules for The Administrations of Juveniles Justice, yang lebih dikenal dengan"The Beijing Rules" dalam Resolusinya No.40/33 Tanggal 29 Nopember 1985 (Peraturan-Peraturan Minimum Standar Perserikatan Bangsa-Bangsa Mengenai Administrasi Peradilan Bagi Anak), yang menyebutkan bahwa:

Sistem peradilan bagi anak mengutamakan kesejahteraan anak, sehingga polisi, penuntut umum dan hakim dalam menangani perkara anak diberi kuasa untuk memutus perkara menurut kebijaksanaan mereka, tanpa menggunakan pemeriksaan awal dan formal, dan berhak untuk mengakhiri proses peradilan pada setiap saat, dan penempatan anak pada suatu lembaga merupakan pilihan terakhir dengan jangka waktu sesingkat mungkin, begitu juga pembebasan bersyarat sejauh mungkin digunakan oleh pihak berwenang yang layak. ${ }^{1}$

Disamping The Beijing Rules, ada "Riyadh Guidelines"(Pencegahan Tindak Pidana Remaja) yaitu United Nations Guidelines for The Prevention of Juvenile Delinquency dalam Resolusi Perserikatan Bangsa-Bangsa No.45/112 Tahun 1990 menyebutkan bahwa: Program untuk pencegahan kenakalan anak/remaja agar dikembangkan guna menjamin perkembangan ke arah proses dewasa anak secara harmonis, dengan mengembangkan kepribadian mereka sejak masa kanak-kanak. Badan-badan pengawasan sosial yang resmi dapat dipergunakan sebagai upaya terakhir, dan penegak hukum yang menangani kenakalan anak harus dilatih agar tanggap

1 Nandang Sambas, 2013, Peradilan Pidana Anak di Indonesia dan Instrumen Internasional Perlindungan Anak Serta Penerapannya, Graha IImu, Yogyakarta, h.62-63 
terhadap kebutuhan anak, dengan berusaha mengalihkan anak dari sistem peradilan. ${ }^{2}$

Kedua resolusi di atas, pada prinsipnya mengatur setiap anak pelaku kejahatan, diwajibkan untuk memperoleh segala bentuk proses peradilan dengan memperlakukan anak secara manusiawi sesuai dengan harkat dan martabatnya.

Atas dasar itu, maka pemidanaan terhadap anak pelaku kejahatan bukan merupakan jalan terbaik karena yang lebih penting adalah rehabilitasi dan pemulihan mengingat anak adalah masa depan bangsa.

\section{B. Rumusan Masalah}

Berdasarkan uraian di atas, dapat dirumuskan masalah sebagai berikut:

1. Apakah penjatuhan pidana penjara terhadap anak pelaku kejahatan sudah sesuai dengan nilai-nilai Pancasila?

2. Penjatuhan sanksi apa yang dapat dijatuhkan terhadap anak pelaku kejahatan agar sesuai dengan nilai-nilai Pancasila?

\section{Tinjauan Pustaka}

\section{a. Pengertian Anak Sebagai Pelaku Kejahatan}

Pengertian anak menurut Kamus Umum Bahasa Indonesia diartikan sebagai manusia yang masih kecil. ${ }^{3}$ Sedangkan menurut Kartini Kartono yang dimaksud dengan anak adalah suatu keadaan manusia yang masih muda dan sedang menentukan identitasnya serta sangat labil jiwanya, sehingga sangat mudah kena pengaruh lingkungannya. ${ }^{4}$ Disamping itu juga, anak dapat diartikan sebagai seorang yang masih di bawah umur dan belum dewasa serta belum kawin. ${ }^{5}$

${ }^{2}$ lbid., h.60

${ }^{3}$ W.J.S.Poerwadarminta, 1976, Kamus Umum Bahasa Indonesia, Batavia, Balai Pustaka, h.735.

4 Kartini Kartono, 1981, Gangguan-gangguan Psikhis, Sinar Baru, Bandung, h.187

5 Romli Atmasasmita, 1983, Problem Kenakalan Anak-anak Remaja, Armico, Bandung, h.25. 
Bob Franklin dalam pendapatnya bahwa being a child is not a universal experience of any fixed duration, but is differently constructed expressing the divergent gender, class, ethnic or historical locations of particulars individuals. Distinctive cultures, as well as histories, construct different worlds of childhood. (Diterjemahkan secara bebas: menyebut seseorang sebagai anak tidaklah memerlukan pengertian terlalu kaku, tetapi memang ada perbedaan jika ditinjau dari sisi gender, etnik, lapisan atau dari latar belakang sejarah masing-masing individu. Perbedaan budaya ini memang secara historis membuat adanya perbedaan pandangan dari sisi anak). ${ }^{6}$

Konvensi tentang hak-hak anak secara tegas menyatakan bahwa "for the purpose of the present convention, a child means every human being below the age of 18 years unles, under the law applicable to the chifd, majority is attained earlier" (diterjemahkan secara bebas: anak dalam konvensi ini adalah setiap orang yang berusia di bawah 18 tahun, kecuali berdasarkan undang-undang yang berlaku bagi anak ditentukan bahwa usia dewasa dicapai lebih awal). ${ }^{7}$

The Beijing Rules (Rules 58) menyebutkan "Juvinile is a child or young person who under the resvektive legal system, may be dealt with for an offence in a menner which is different from a adult. (Diterjemahkan secara bebas: anak-anak adalah seorang anak atau remaja yang menurut sistem hukum masing-masing dapat diperlakukan sebagai pelaku suatu pelanggaran dengan cara yang berbeda dari seorang dewasa)

Selanjutnya dari aspek hukum pidana, walaupun secara tegas sudah ditentukan berdasarkan pada batas umur, namun masih bervariatif. Seperti Undang-Undang No.4 Tahun 1979 Tentang Kesejahteraan Anak dalam Pasal 1 ayat (2) memberikan pengertian anak adalah seorang yang belum mencapai umur 21 tahun dan belum pernah kawin. Begitu juga menurut Pasal 1 angka1 Undang-Undang No. 35 Tahun 2014 Tentang Perlindungan Anak ditentukan bahwa anak adalah seseorang yang belum berusia 18 (delapan belas) tahun termasuk anak yang masih dalam

${ }^{6}$ Bob Franklin, 1955, The Case for Children's Right: a Progress Report. Dalam the Handbook of Children's Rights: Comperative Policy and Practice. Disunting oleh Bob Franklin, Routledge, London, p.3

7 United Nations Children's Fund, Convention on the Rights of the Child, Resolusi PBB, No.44/25, 20 November 1989 
kandungan. Batasan pengertian anak seperti tresebut sangat bervariatif dari segi yuridis yang berlaku, sehingga menimbulkan persoalan untuk menentukan pertanggungjawaban dari tindak pidana yang dilakukan.

Ada 2 (dua) kategori terhadap perilaku anak yang membuat anak disebut sebagai pelaku yaitu:

1. Status Offence yaitu perilaku kenakalan anak yang apabila dilakukan oleh orang dewasa tidak dianggap sebagai kejahatan, seperti tidak menurut, membolos sekolah atau kabur dari rumah;

2. Juvenile Deliquency yaitu perilaku kenakalan anak yang apabila dilakukan oleh orang dewasa dianggap kejahatan atau pelanggaran hukum. ${ }^{8}$

Di Amerika Serikat, ada pembedaan antara perbuatan yang dilakukan oleh anak dengan orang dewasa. Suatu tindakan antisosial yang melanggar norma hukum pidana, kesusilaan, ketertiban umum, yang apabila dilakukan oleh seseorang yang berusia di atas 21 tahun, maka perbuatannya itu disebut kejahatan (crime). Namun jika dilakukan oleh seseorang yang usianya di bawah 21 tahun disebut kenakalan (Deliquency). ${ }^{9}$

Kenakalan anak diambil dari istilah "juvenile delinquency", yang berasal dari kata juvenile yang artinya "young" anak-anak, anak muda, ciri karakteristik pada masa muda, sifat-sifat khas pada periode remaja. Sedangkan delinquency artinya "wrong doing", terabaikan/mengabaikan, yang kemudian diperluas menjadi jahat, a-sosial, kriminal, pelanggar aturan, pembuat rebut, pengacau, penteror, tidak dapat diperbaiki lagi, durjana, dursila. ${ }^{10}$

Istilah kenakalan anak pertama kali terungkap pada Badan Peradilan Anak di Amerika serikat, dalam rangka membentuk suatu Undang-Undang bagi anak di negara tersebut. Dalam pembahasannya ada kelompok yang menekankan segi pelanggaran hukumnya, adapula

8 Purnianti, dkk, mengutip Harry E.Allen and Clifford E. Simmonsen, terjemahan Correction in America: An Introduction, Analisa Situasi Sistem Peradilan Pidana Anak (Juvenile Justice System) di Indonesia, UNICEF, Indonesia, 2003, h.2

9 Nashrina, Perlindungan Hukum Pidana Bagi Anak Indonesia, Raja Grafindo Persada, Jakarta, h.31

$10 \mathrm{lbid}$, h.25. 
kelompok yang menekankan pada sifat tindakan anak apakah sudah menyimpang dari norma yang berlaku atau belum melanggar hukum. Namun semua sependapat bahwa dasar pengertian kenakalan anak adalah perbuatan atau tingkah laku yang bersifat antisosial.

Menurut Paulus Hadisuprapto, walaupun secara etimologis juvenile delinquency dapat berarti kejahatan anak, namun istilah kejahatan anak ini terasa terlalu tajam dan memiliki konotasi negatif secara kejiwaan terhadap anak. Sehingga untuk menterjemahkan istilah juvenile delinquency dipilih istilah Bahasa Indonesia yaitu "perilaku delinkuensi anak". ${ }^{11}$ Berbeda halnya dengan pandangan Bimo Walgito yang mengartikan juvenile delinquency adalah tiap perbuatan, jika perbuatan tersebut dilakukan oleh orang dewasa, maka perbuatan itu merupakan kejahatan, dan merupakan perbuatan yang melawan hukum jika dilakukan oleh anak, sehingga dari sini maka ada istilah kenakalan remaja menjadi populer. ${ }^{12}$

\section{b. Pengertian Pidana Alternatif}

Berkaitan dengan pembaruan hukum pidana, kebijakan menetapkan sanksi pidana dalam perundang-undangan merupakan tahap yang paling sentral dan strategis dilihat dari keseluruhan proses kebijakan untuk mengoperasionalisasikan sanksi pidana. Menurut Muladi, "upaya melakukan pembaruan hukum pidana, ada gerakan reformis yang berusaha untuk mencari alternatif dari pidana penjara, dan bentuk-bentuk alternative sanction diantaranya pidana pengawasan, pidana kerja sosial". ${ }^{13}$

Dilihat dari sejarahnya, sebenarnya usaha untuk mencari pidana alternatif (alternative sanction) sudah sejak lama dilakukan di dalam rangka criminal policy, hal ini sering menjadi bahan diskusi pada pelbagai kongres dan konferensi Internasional pada akhir abad ke-19 yang menghimbau

11 Paulus Hadisuprapto, 1997, Juvenile Delinquency, Pemahaman dan Penanggulangannya,Citra Aditya Bakti, bandung, h.12

12 Sudarsono, 1995, Kenakalan Remaja, Rineka Cipta, Jakarta, h.10-11

${ }^{13}$ Muladi, 1985, Lembaga Pidana Bersyarat, Alumni, Bandung, h.150 
agar para negara peserta mengembangkan pelbagai alternative to short custodial sentence. ${ }^{14}$

Terdapat dua pandangan tentang penerapan pidana alternatif (alternative sanction), yaitu ada anggapan bahwa pidana alternatif hanya dapat diterima bilamana sanksi tersebut dapat melayani tujuan dari kegunaan pidana penjara yang dianggap tidak efektif. Dan pendapat lainnya, sanksi alternatif merupakan usaha mencapai tujuan-tujuan alternatif (alternative goals) yang tidak dapat dicapai dengan pidana penjara. ${ }^{15}$ Berdasarkan hal itu, menurut Muladi "sanksi alternatif hanya cocok untuk fungsinya sebagai reformasi, reedukasi dan rehabilitasi, karena memanag tujuannya untuk menggantikan pidana penjara". ${ }^{16}$

Sebagai upaya untuk melakukan reformasi dan reevaluasi terhadap penjatuhan pidana khususnya kepada anak, Undang-Undang No.11 tahun 2012 Tentang Sistem Peradilan Pidana Anak telah dirumuskan jenis pidana dalam Pasal 71 antara lain:

(1) Pidana pokok bagi anak terdiri atas:

a. Pidana peringatan;

b. Pidana dengan syarat:

1) Pembinaan di laur lembaga

2) Pelayanan masyarakat, atau

3) pengawasan

c. pelatihan kerja;

d. pembinaan dalam lembaga; dan

e. Pidana penjara.

(2) Pidana tambahan terdiri atas:

a. Perampasan keuntungan yang diperoleh dari tindak pidana; atau

b. Pemenuhan kewajiban adat.

Penentuan jenis pidana seperti itu merupakan suatu fleksibilitas dalam memperlakukan anak pelaku tindak pidana, dan merupakan suatu upaya memberikan perlindungan kepada masyarakat. Di samping itu,

14 Ibid, h. 161

15 Anonim, tanpa tahun, Pidana Pengawasan dalam Kebijakan Pembaruan Hukum Pidana Indonesia, hasil penelitian, h.8

16 Muladi, Op Cit, h.162 
fleksibilitas perlakuan anak juga merupakan upaya untuk menghindari penggunaan hukuman penjara yang tidak perlu. Untuk itu, sistem peradilan pidana perlu menyediakan suatu cakupan tindakan yang luas karena berkenaan dengan upaya non penahanan, pra persidangan menuju pasca penempatan penghukuman. Apabila terdapat kelayakan dan kesesuaian dengan sistem hukum, polisi, penuntut umum atau aparat penegak hukum lainnya yang berhadapan dengan kasus tindak pidana harus diberdayakan untuk memberikan perlindungan terhadap masyarakat, mencegah tindak pidana, dan memajukan penghormatan terhadap hukum dan hak korban.

\section{PEMBAHASAN}

\section{a. Karakteristik Pidana Pengawasan dalam Pembaharuan Hukum Pidana}

Sesungguhnya, filosofi dari pemidanaan adalah untuk menentukan rasa keadilan bilamana telah terjadi pelanggaran terhadap hukum pidana. Berdasarkan hasil laporan Simposium Pembaharuan Hukum Pidana Nasional Tahun 1980 tujuan pemidanaan harus diarahkan kepada perlindungan masyarakat dengan memperhatikan kepentingan masyarakat/negara, korban, dan pelaku". Sesungguhnya tujuan pemidanaan telah mengalami perubahan sesuai dengan Rancangan KUHP (2012) yang dirumuskan dalam Pasal 54 sebagai berikut:

(1) Pemidanaan bertujuan :

a. Mencegah dilakukannya tindak pidana dengan menegakkan norma hukum demi pengayoman masyarakat;

b. Memasyarakatkan terpidana dengan mengadakan pembinaan sehingga menjadi orang yang baik dan berguna;

c.Menyelesaikan konflik yang ditimbulkan oleh tindak pidana, memulihkan keseimbangan, dan mendatangkan rasa damai dalam masyarakat; dan

d. Membebaskan rasa bersalah pada terpidana.

(2) Pemidanaan tidak dimaksudkan untuk menderitakan dan merendahkan martabat manusia.

Begitu pula dalam Pasal 55 diatur perihal pedoman pemidanaan yaitu:

(1) Dalam pemidanaan wajib dipertimbangkan : 
a. Kesalahan pembuat tindak pidana;

b. Motif dan tujuan melakukan tindak pidana;

c. Sikap batin pembuat tindak pidana;

d. Tindak pidana yang dialkukan apakah direncanakan atau tidak;

e. Cara melakukan tindka pidana;

f. Sikap dan tindakan pembuat sesudah melakukan tindak pidana;

g. Riwayat hidup, keadaan sosial, dan keadaan ekonomi pembuat tindak pidana;

h. Pengaruh pidana terhadap masa depan pembuat tindak pidana;

i. Pemaafan dari korban dan/atau keluarganya; dan atau

j. Pandangan masyarakat terhadap tindak pidana yang dilakukan.

(2) Ringannya perbuatan, keadaan pribadi pembuat, atau keadaan pada waktu dilakukan perbuatan atau yang terjadi keudian, dapat dijadikan dasar pertimbangan untuk tidak menjatuhkan pidana atau mengenakan tindakan dengan mempertimbangkan segi keadilan dan kemanusiaan.

Persoalan filosofis timbul ketika anak sebagai pelaku kejahatan, hukuman yang dijatuhkan berupa pidana penjara, hal tersebut tentunya bertentangan dengan nilai-nilai Pancasila yang tertuang di dalam sila ke-2 "kemanusiaan". Selanjutnya persoalan secara teoritis yang dapat timbul adalah, selama ini penjatuhan pidana terhadap anak, dalam pelaksanaannya anak masih diposisikan sebagai objek, sehingga cenderung merugikan anak. Peran hakim dalam hal ini lebih banyak dibandingkan dengan peran penyidik dan penuntut umum, karena masih digunakan model keadilan retributif yang lebih menonjolkan penghukuman, dan belum diatur tentang diversi yaitu model keadilan restoratif yang berupa pengalihan perkara anak di luar jalur peradilan formal. Sebagai akibatnya model keadilan retributif di masyarakat belum mampu memberikan perkembangan mental anak yang memadai, tapi justru memberikan pengaruh buruk yaitu terjadi stigmatisasi dan prisionisasi terhadap anak. 
Pemerintah Indonesia dalam upayanya memberikan perlindungan terhadap anak pelaku kejahatan, telah mengeluarkan Undang-Undang No.11 Tahun 2012 Tentang Sistem Peradilan Pidana Anak yaitu dalam Pasal 71 ditentukan salah satu jenis pidana sebagai pidana alternatif berupa "pidana pengawasan" yang dirumuskan dalam Pasal 77:

(1) Pidana pengawasan yang dapat dijatuhkan kepada anak sebagaimana dimaksud dalam Pasal 71 ayat (1) huruf $b$ angka 3 paling singkat 3 (tiga) bulan dan paling lama 2 (dua) bulan.

(2) Dalam hal anak dijatuhi pidana pengawasan sebagaimana dimaksud pada ayat (1), anak ditempatkan di bawah pengawasan Penuntut Umum dan dibimbing oleh Pembimbing Kemasyarakatan.

Kitab Undang-Undang Hukum Pidana yang disingkat KUHP Indonesia tidak mengatur tentang pidana pengawasan, dan mulai diatur sejak dikeluarkan Undang-Undang No.3 Tahun 1997 tentang Pengadilan Anak, begitu juga di dalam Rancangan KUHP tahun 2012 telah diatur dalam Pasal 77-79. Menurut Muladi di berbagai negara telah berusaha untuk mencari cara-cara lain dari penjatuhan pidana penjara yang berupa peningkatan pemidanaan yang bersifat non-institusional. ${ }^{17}$ Sesuai dengan tujuan aliran "defence social" yang hendak menghilangkan bahaya terhadap masyarakat dengan mengadakan resosialisasi dari pembuat. Karena hukum pidana dipertahankan sebagai salah satu sarana untuk "social defence" dalam arti melindungi masyarakat terhadap kejahatan dengan memperbaiki atau memulihkan kembali (rehabilitasi) si pembuat tanpa mengurangi keseimbangan perorangan (pembuat) dan masyarakat. 18 Oleh sebab itu, penjatuhan pidana penjara terhadap anak pelaku kejahatan bukan merupakan jalan terbaik karena yang lebih penting adalah rehabilitasi dan pemulihan mengingat anak adalah masa depan bangsa.

Howard Jones dalam bukunya Crime and The Penal System mengemukakan karakteristik pidana pengawasan yaitu before one

17 Muladi, 1992, Lembaga Pidana Bersyarat, Alumni, Bandung, h.5

${ }^{18}$ Sudarto, 1986, Hukum dan Hukum Pidana, Alumni, Bandung, h.58-59 
can speak of probation in the modern sense, all of the following conditions must be present (sebelum seseorang dapat berbicara tentang masa percobaan dalam pengertian modern, semua kondisi berikut harus hadir):

(1) No punishment is imposed initially (tidak ada hukuman dikenakan awalnya);

(2) The offenders is given a fixed period to redeem himself (pelanggar diberi jangka waktu tertentu untuk menebus dirinya);

(3) During this period he is placed under the supervision of a probation officer (a) in order to keep the court informed of his progress, (b) to help him to make the best of the opportunity given to him (selama periode ini ia ditempatkan di bawah pengawasan ini dari (a) untuk menjaga pengadilan dari informasi kemajuan, (b) untuk membantu dia untuk membuat yang terbaik dari kesempatan yang diberikan kepadanya;

(4) If he makes good, the original crime is considered to have been purged, but if he fails to do so, he may be brought back into court and sentenced for this, as well as for any other crime he may have committed since ( jika ia membuat baik, kejahatan asli dianggap telah dibersihkan, tapi jika ia gagal untuk melakukannya, ia dapat dibawa kembali ke pengadilan dan dijatuhkan hukuman untuk ini, serta untuk kejahatan lain ia mungkin telah berkomitmen). ${ }^{19}$

Keempat karakteristik pidana pengawasan yang dirumuskan oleh Howard Jones di atas, dapat dirumuskan sebagai berikut:

(1) Pada awalnya terhadap pelaku belum dikenai suatu hukuman yang dikaitkan dengan perampasan kemerdekaan. Pelaku tetap diperkenankan untuk menikmati kebebasannya menjalani kehidupannya secara normal di tengah-tengah masyarakat;

(2) Terhadap pelaku ditetapkan suatu jangka waktu tertentu untuk memperbaiki dirinya;

(3) Selama jangka waktu ( sebagai masa percobaan) pelaku ditempatkan di bawah pengawasan pejabat pengawas dalam rangka melaporkan secara kontinyu perkembangan dan 
membantu si pelaku dalam menggunakan kesempatan/kebebasan yang diberikan padanya ini dengan sebaik-baiknya;

(4) Jika pelaku dalam masa percobaan tersebut dapat berkelakuan baik, maka kejahatan yang telah dilakukannya dipertimbangkan untuk diberikan pengampunan. Akan tetapi bila pelaku gagal, maka pelaku kemungkinan akan dihadapkan kembali ke depan persidangan dan dijatuhi pidana atas kejahatan tersebut, begitu pula bila jika melakukan bentuk kejahatan lainnya

Keempat karakteristik di atas dapat penulis cermati, nampaknya dengan pidana pengawasan, tidak menimbulkan "stigma" pada anak, akibat adanya penundaan penjatuhan pidana (belum dikenai suatu hukuman), karena pelaku masih diberikan kesempatan untuk memperbaiki diri. Pengawasan dapat dilakukan, disesuaikan dengan kebutuhan pembinaan terhadap pelaku terkait pada keadaan pribadi pelaku, keadaan perbuatannya, kemudian kerugian yang ditimbulkan terhadap korban, juga disesuaikan dengan filsafat pembinaan yang berdasarkan pada asas "kemanusiaan".

Menurut Howard Jones "probation orders may be made for any period of from one to three years....." (pelaksanaan pidana pengawasan dapat dilakukan selama waktu tertentu atau dalam jangka waktu 1- 3 tahun). ${ }^{20}$ Demikian juga seperti yang diatur dalam ketentuan hukum pidana di Portugal mengenai probation order ditentukan bahwa orang yang diberi "probation" menjadi sasaran rencana rehabilitasi di bawah pengawasan untuk jangka waktu 1-3 tahun. Begitu pula di Portugal, pelaku diberikan probation menjadi sasaran rencana rehabilitasi di bawah pengawasan untuk jangka waktu 1-3 tahun.

Undang-Undang No.11 Tahun 2012 Tentang Sistem Peradilan Pidana Anak yaitu Pasal 77 ayat (1) ditentukan jangka waktu pengawasan paling singkat 3 (tiga) bulan dan paling lama 2 (dua) tahun, dan tidak ada ketentuan tentang jangka waktu yang dapat diperpanjang. Akibatnya, dari keadaan tersebut, bilamana ada hal-hal tertentu selama masa pengawasan, maka jangka waktu 2 (dua) tahun tidak dapat ditinjau kembali. Jangka waktu 2 (dua) tahun yang sudah ditentukan dipandang

${ }^{20}$ Howard Jones, Op Cit, h.255 
cukup dalam melakukan pengawasan terhadap anak, namun untuk menghindari hal-hal yang dapat merugikan anak selama menjalani pengawasan, menurut penulis, selayaknya diatur juga rumusan yaitu "pengawasan dapat diperpanjang" sebagaimana yang ditentukan dalam Pasal 78 ayat (5) Rancangan KUHP (2012).

\section{b. Pidana Pengawasan yang Berlandaskan Filsafat Pancasila}

Pembangunan sistem hukum pidana Indonesia sudah saatnya untuk meninggalkan nilai-nilai hukum asing pemerintah kolonial Belanda, karena pengalaman telah menunjukkan untuk segera menggantikannya dengan menggunakan sistem hukum yang selaras dengan pandangan hidup bangsa Indonesia. Pancasila dalam kedudukannya sebagai sumber dari segala sumber hukum, dalam membangun sistem hukum pidana harus diletakkan dalam kedudukannya yang paling tinggi.

Menurut Sunaryati Hartono, "kebhinekaan yang terjadi di Indonesia, justru dirangkum dalam Pancasila, yang menjadi arah pembentukan sistem hukum pidana, karena kebhinekaan merupakan asas hukum yang harus menentukan dan mewarnai hukum nasional yang dibentuk". ${ }^{21}$

Padmo Wahyono dalam pendapatnya mengatakan bahwa "pengayoman yang merupakan fungsi hukum Indonesia harus mampu menegakkan kehidupan yang demokratis, berkeadilan sosial dan berperikemanusiaan, karena ketiga hal tersebut akan menjadi petunjuk dan memberi warna dasar pada hukum Indonesia". ${ }^{22}$ Berdasarkan hal itu, maka secara yuridis filosofis Pancasila sebagai sumber hukum yang memberikan kesamaan hak dan kewajiban dalam fungsinya sebagai pengayoman. Dalam keadaan yang demikian, maka Indonesia sudah sepatutnya untuk membangun sistem hukum sendiri berdasarkan nilai-nilai hukum yang hidup dalam masyarakat, dengan mengangkat nilai-nilai yang luhur dan mulia. $^{23}$

21 Sunaryati Hartono, 2006, Bhineka Tunggal Ika, sebagai Asas Hukum Bagi Pembangunan Hukum Nasonal, Penerbit PT.Citra Aditya Bakti, Bandung. H.49

22 Padmo Wahyono, 1989, Pembangunan Hukum di Indonesia, Penerbit Ind-Hill-co, Jakarta, h.40

$23 \mathrm{lbid}$ 
Mengingat Pancasila dalam tata hukum Indonesia masih bersifat abstrak, maka untuk menkonkritkan dan mengoperasionalkan dalam tata hukum dan penegakan hukumnya, pencapaian hak asasi manusia (HAM) menjadi ukuran yang harus diimplementasikan dalam tata hukum. Karena penggunaan konsep HAM tidak bisa dilepaskan dari substansi hukum, Koesparmono Irsan mengatakan bahwa, HAM merupakan hak dasar yang secara kodrati melekat pada diri manusia bersifat universal dan langgeng, sehingga harus dilindungi dan dihormati, dipertahankan dan tidak boleh diabaikan, dikurangi atau dirampas oleh siapapun ${ }^{24}$.

Di abad ke-21 ini, hukum pidana perlu dilakukan reformasi dan reorientasi diantaranya:

a. Hukum tidak bebas nilai dari asas perikemanusiaan yang bersumber dari hak asasi manusia;

b. Hukum yang harus mengandung peradaban manusia yang semakin maju;

c. Hukum harus menumbuhkan kesejahteraan bersama yang bersumber dari aspek sosial sebagai pelayanan hukum;

d. Tatanan hidup manusia tidak cukup hanya mengandalkan aturan hukum, tetapi juga harus dilengkapi oleh norma moral di lingkungan masyarakat atau penguasa. ${ }^{25}$

Penulis setuju dengan pendapatnya Roeslan Saleh bahwa "salah satu tujuan dari penjatuhan pidana adalah "resosialisasi" yaitu penjatuhan pidana dilandasi pemikiran bahwa pelaku cepat atau lambat akan kembali ke masyarakat, sehingga perlu dipersiapkan agar yang bersangkutan menjadi orang yang berguna". ${ }^{26}$ Demikian pula menurut pandangannya Muladi bahwa "dalam hal penjatuhan pidana, semestinya yang dianut adalah yang realistik yaitu memperhatikan pelbagai kepentingan yang harus dilindungi oleh hukum pidana yaitu kepentingan negara, kepentingan umum, kepentingan individu, kepentingan pelaku, dan kepentingan korban, yang bertumpu pada konsep daad-daderstrafrecht

24 Koesparmono Irsan, 2009, Hukum dan Hak Asasi Manusia, Brata Bakti, Jakarta, h.32

25 Teguh Prasetyo, Op Cit, h.184

${ }^{26}$ Roeslan Saleh, 1987, Stelsel Pidana Indonesia, Aksara Baru, Jakarta, h.7 
yang disebut dengan "model keseimbangan kepentingan". ${ }^{27}$ Begitu pula agar penjatuhan pidana lebih bersifat lunak atau tidak bersifat represif, maka model kekeluargaan (family model) dan model pengayoman dapat diterapkan, karena dengan model kekeluargaan, baik pelaku maupun korban begitu juga masyarakat dapat berpartisipasi dalam penyelesaian masalah hukum, karena pelaku diwajibkan untuk memulihkan kerugian materiil yang ditimbulkan oleh tindak pidana, dan korban didengar aspirasinya, serta masyarakat menjadi mediator dalam penyelesaian kasus tersebut.

Mahfud MD menegaskan, hukum yang ada dalam suatu negara haruslah sesuai dengan ide atau cita hukum dan realitas masyarakat dimana hukum itu memberi pelayanan. ${ }^{28}$ Karena hukum yang ada atau dibentuk tersebut tidak dapat dilepaskan dari masyarakatnya sebagai subjek yang akan dilayaninya, sehingga penyesuaian produk hukum dengan keadaan masyarakat menjadi sangat penting. Oleh karena itu, penentuan pidana pengawasan terhadap anak yang telah melakukan kejahatan pada masa sekarang ini merupakan suatu upaya dalam hal melakukan pembinaan terhadap anak secara manusiawi, dengan tetap menjunjung tinggi harkat dan martabatnya agar dapat menjadi manusia yang utuh, sesuai dengan asas-asas yang tertuang di dalam UndangUndang No.11 Tahun 2012 antara lain:

a. Asas keadilan bahwa setiap penyelesaian perkara anak harus mencerminkan rasa keadilan bagi anak;

b. Asas nondiskriminasi yaitu tidak adanya perlakuan yang berbeda didasarkan pada suku, agama, ras, golongan, jenis kelamin, etnik, budaya, dan bahasa, status hukum anak, urutan kelahiran anak, serta kondisi fisik dan/atau mental;

c. Asas kepentingan terbaik bagi anak maksudnya adalah segala pengambilan keputusan harus selalu mempertimbangkan kelangsungan hidup dan tumbuh kembang anak;

${ }^{27}$ Muladi, Op Cit, h.5

28 Mahfud MD, 1997, Pembaharuan Hukum Nasional sebagai Amanat Proklamasi dan Konstitusi, dalam Jurnal Hukum, No.7, Vol.4 Fakultas Hukum UII, h. 17 
d. Asas penghargaan terhadap pendapat anak yaitu penghormatan atas hak anak untuk berpartisipasi dan menyatakan pendapatnya dalam pengambilan keputusan, terutama jika menyangkut hal yang mempengaruhi kehidupan anak;

e. Asas kelangsungan hidup dan tumbuh kembang anak adalah hak asasi yang paling mendasar bagi anak yang dilindungi oleh negara, pemerintah, masyarakat, keluarga dan orang tua;

f. Asas pembinaan dan pembimbingan anak. Pembinaan yang dimaksudkan adalah kegiatan untuk meningkatkan kualitas, ketaqwaan kepada Tuhan Yang Maha Esa, intelektual, sikap dan perilaku, pelatihan ketrampilan, professional, serta kesehatan jasmani dan rohani anak baik di dalam maupun di luar proses peradilan pidana. Sedangkan pembimbingan adalah pemberian tuntutan untuk meningkatkan kualitas ketaqwaan kepada Tuhan Yang Maha Esa, intelektual, sikap dan perilaku, pelatihan keterampilan, professional, serta kesehatan jasmani dan rohani klien pemasyarakatan;

g. Asas proporsional maksudnya adalah segala perlakuan terhadap anak harus memperhatikan batas keperluan, umur, dan kondisi anak;

h. Asas perampasan kemerdekaan merupakan upaya terakhir yang pada dasarnya anak tidak dapat dirampas kemerdekaannya, kecuali terpaksa guna kepentingan penyelesaian perkara;

i. Asas penghindaran pembalasan adalah prinsip menjauhkan upaya pembalasan dalam proses peradilan pidana.

Atas dasar itu, relevansi pidana pengawasan yang berlandaskan pada filsafat pembinaan terhadap anak sebagai pelaku kejahatan, sesuai dengan aliran "defence social nouvele" (perlindungan masyarakat baru) dari Marc Ancel. Karena gerakan ini menghendaki inividualisasi dari pidana dan resosialisasi pada pelaku, pemidanaan diarahkan pada pembinaan, dan pembinaan itu sendiri merupakan suatu bentuk umum untuk perlindungan masyarakat. Itu berarti pidana pengawasan juga relevan 
sebagai salah satu alat dalam upaya penanggulangan dari timbulnya kejahatan khususnya terhadap anak. ${ }^{29}$

\section{Kesimpulan}

1. Penjatuhan pidana penjara terhadap anak pelaku kejahatan dapat menyebabkan ketidakadilan pada anak, karena anak memperoleh status labelisasi/stigmatisasi yang akan terbawa sampai anak dewasa. Hal ini tentunya tidak sesuai dengan nilai-nilai yang tertuang dalam Pancasila khususnya sila "kemanusiaan", karena kesempatan anak untuk melanjutkan kehidupannya agar menjadi manusia yang utuh sudah tidak dapat dicapai seperti hak untuk melanjutkan pendidikan, hak untuk tumbuh kembang yang sesuai dengan harkat dan martabatnya

2. Pidana pengawasan sebagai pidana alternatif dapat melindungi hak-hak anak, karena dalam pidana pengawasan mengandung unsur-unsur yang terkait dengan kemanusiaan, edukatif dan keadilan. Menurut ilmu psychology, anak yang telah melakukan perbuatan yang menyimpang tidak dapat disembuhkan dengan hukuman dan siksaan, tetapi dengan terapi mental agar dapat menjadi sadar dan jera. Dengan demikian, hak-hak anak untuk dapat hidup, tumbuh dan berkembang akan dapat terpenuhi.

\section{Saran-saran:}

1. Agar upaya memberikan perlindungan terhadap anak pelaku kejahatan dapat dilaksanakan baik secara filisofis, yuridis dan sosiologis, maka pemerintah agar segera menerbitkan Peraturan Pelaksana dari Undang-Undang No.11 Tahun 2012 Tentang Sistem Peradilan Pidana Anak,

2. Agar melalui pidana pengawasan dapat terpenuhinya hak-hak anak pelaku kejahatan diantaranya hak untuk tumbuh dan berkembang sesuai dengan harkat dan martabatnya, pemerintah agar segera membuatkan payung hukum perihal kualifikasi penegak hukum yang menangani masalah anak agar putusannya lebih relevan dalam memberikan perlindungan terhadap anak.

\footnotetext{
${ }^{29}$ Sudarto V, Op Cit, h.68
} 


\section{DAFTAR PUSTAKA}

\section{Buku}

Arief, Barda Nawawi, 1996, Bunga Rampai Hukum Pidana, PT.Citra Aditya Bakti, Bandung.
--------------------, 2000, Kebijakan Legislatif dan Penanggulangan
Kejahatan dengan Pidana Penjara, Badan Penerbit UNDIP, Semarang

Pidana, PT.Raja Grafindo Persada, Jakarta.

Cross, Rupert, 1975, The English Sentencing System, Butterworths, London.

Daulay, Nurussakinah, 2014, Pengantar Psikologi, Prenadamedia, Jakarta Franklin, Bob, 1955, The Case for Children's Right: a Progres Report, dalam The Handbook of Chindren's Right: Comperative Policy and Practice. Disunting oleh Bob Franklin, Routledge, London.

Gosita, Arif, 1993, Masalah Korban Kejahatan, Akademika Pressindo, Jakarta

1989, Masalah Perlindungan Anak, Akademika Pressindo, Jakarta.

Hadisuprapto, Paulus, 1997, Juvenile Delinquency, Pemahaman dan Penanggulangannya, Citra Aditya Bakti, Bandung

Hulsman, LHC, 1978, The Dutch Criminal Justice System From a Comperative Legal Perspective

Joni, Muhammad dan Zulchaina Z.Tanamas, 1999, Aspek hukum Perlindungan Anak dalam Perspektif Konvensi Hak Anak, PT.Citra Aditya Bakti, Bandung.

Jonkers, JE, 1987, Buku Pedoman Hukum Pidana Hindia Belanda, Bina Aksara, Jakarta.

Kartono, Kartini, 1981, Gangguan-Gangguan Psikis, Sinar Baru, Bandung Mannhim, Hermann, 1946, Criminal Justice and Social Reconstruction, Oxford University Press, New York

Muladi, 1985, Lembaga Pidana Bersyarat, Alumni, Bandung --------, 1992, Lembaga Pidana Bersyarat, Alumni, Bandung. 
--------, 2002, Hak Asasi Manusia, Politik dan Sistem Peradilan Pidana, Penerbit, UNDIP, Semarang.

Muladi, dan Barda Nawawi Arief, 1998, Kapita Selkta Kebijakan Hukum Pidana, Alumni, Bandung

Nashrina, 2012, Perlindungan Hukum Pidana Bagi Anak di Indonesia, Raja Grafindo Persada, Jakarta

Nonet, Philippe dan Philip Selznick, 1978, Law and Sociaty in Transition, Toward Responsive Law, Herper Colophon Books.

Platt, Anthony M, 2009, Peradilan Pidana Anak di Indonesia, Terjemahan Marlina, Refika Aditya, Bandung.

Purnianti, 2003, Analisa Situasi Sistem Peradilan Pidana Anak (Juvenile Justice System) di Indonesia, UNICEF, Indonesia

Sadhi Astuti, Made, 2003, Hukum Pidana Anak dan Perlindungan Anak, Universitas Negeri Malang, Malang.

Sambas, Nandang, 2013, Peradilan Pidana Anak di Indonesia dan Instrumen Internasional Perlindungan Anak Serta Penerapannya, Graha IImu, Yogyakarta.

Sholehuddin, M, 2003, Sistem Sanksi dalam Hukum Pidana, Ide Dasar Doube Track System dan Implementasinya, Rajawali, Jakarta

Sigit Pramukti, Angger, 2015, Sistem Peradilan Pidana Anak, Pustaka Yustisia, Yogyakarta.

Sudarto, 1986, Hukum dan Hukum Pidana, Alumni, Bandung.

Sudarsono, 1995, Kenakalan Remaja, Rineka Cipta, Jakarta.

\section{Peraturan Perundang-Undangan}

Undang-Undang Dasar Negara Republik Indonesia 1945

Kitab Undang-Undang Hukum Pidana

Undang-Undang No.11 Tahun 2012 Tentang Sistem Peradilan Pidana Anak

Undang-Undang No.12 Tahun 1995 Tentang Kesejahteraan Anak Undang-Undang No.35 Tahun 2014 Tentang Perlindungan Anak 


\section{Makalah/Artikel}

Anonim, tanpa tahun, Pidana Pengawasan dalam Kebijakan Pembaruan Hukum Pidana Indonesia, Hasil Penelitian.

Arief, Barda Nawawi, 2005, Perkembangan Sistem Pemidanaan di Indonesia, Makalah, Penataran Nasional Hukum Pidana dan Kriminologi, Fakultas Hukum Universitas Surabaya, Surabaya.

Campbel Black, Henry, 1979, Black's Law Dictionary, Fifth Edition, St Paul Minn West Publishing.

Muladi, Proyeksi Hukum Pidana Materiil di Masa Datang, Pidato Pengukuhan Guru Besar Ilmu Hukum UNDIP, Semarang.

Mudzakir, 2001, Posisi Hukum Korban Kejahatan dalam Sistem Peradilan Pidana, Ringkasan Disertasi Program Pascasarjana FH UI, Jakarta Siswanto, Slamet, 2012, Pidana Pengawasan dalam Sistem Pemidanaan di Indonesia, Tesis, Program Pascasarjana Ilmu Hukum, UNDIP, Semarang 